\title{
Nurmen ravinnetasetutkimus pohjoissavolaisilla tiloilla
}

\author{
Tiina Hyvärinen ${ }^{1)}$, Anu Rossi ${ }^{1)}$, Maarit Hyrkäs²) ja Mari Räty²) \\ 1) ProAgria Pohjois-Savo, Puijonkatu 1470110 Kuopio etunimi.sukunimi(at)proagria.fi \\ ${ }^{2)}$ Luonnonvarakeskus (Luke), Tuotantojärjestelmät, Halolantie 31 A, 71750 Maaninka, \\ etunimi.sukunimi(at)luke.fi
}

Maatilojen ravinnevirtoja tutkittiin kasvukauden 2016 aikana kolmella pohjoissavolaisella maidontuotantotilalla. Tutkimukseen valittiin jokaiselta havaintotilalta eri-ikäinen säilörehulohko. Ennen säilörehunkorjuuta lohkoille tehtiin havaintokäynti, jossa tarkasteltiin lohkon tuoresadon määrää, nurmen aukkoisuutta ja rikkakasvipitoisuutta päisteen, pellon ja renkaanjäljen välillä. Tulosten perusteella sadon määrä päisteissä voi olla merkittävästi matalampi kuin renkaan jäljissä tai muualla pellolla ( $\mathrm{P}<0.001)$. Pellon ja renkaanjäljen välillä oli hyvin vähän eroa sadon määrässä tämän aineiston perusteella. Lohkon säilörehukuormat punnittiin ajoneuvovaa'alla lohkon satotason selvittämistä varten. Saadut satotasot olivat ensimmäisen vuoden nurmesta $7900 \mathrm{~kg} \mathrm{ka} \mathrm{ha}^{-1}$, toisen vuoden nurmesta $9100 \mathrm{~kg}$ $\mathrm{ka} \mathrm{ha}^{-1}$ ja neljännen vuoden nurmesta $5500 \mathrm{~kg} \mathrm{ka} \mathrm{ha}^{-1}$. Säilörehuanalyysin, satotason ja toteutuneen lannoituksen perusteella laskettiin lohkoille ravinnetaseet. Ravinnetaseiden avulla voidaan tarkastella, onko lohkolta saatu satotaso ja lannoitus tasapainossa. Lannoitus on onnistunut ravinnetaseen ollessa lähellä nollaa tai negatiivinen. Lannoitus toteutettiin fosforin ja kaliumin osalta pääosin naudan lietelannalla, jota täydennettiin typpi- ja kaliumlannoitteilla. Fosforin ravinnetaseet olivat negatiiviset jokaisella havaintolohkolla ( $\left.-8 \mathrm{~kg} \mathrm{ha}^{-1},-20 \mathrm{~kg} \mathrm{ha}^{-1},-7 \mathrm{~kg} \mathrm{ha}^{-1}\right)$ ja samoin kaliumin ravinnetaseet (-133 $\left.\mathrm{kg} \mathrm{ha}^{-1},-204 \mathrm{~kg} \mathrm{ha}^{-1},-55 \mathrm{~kg} \mathrm{ha}^{-1}\right)$. Typpitase on laskettu liukoisella typellä sekä kokonaistypellä. Kokonaistyppitaseet olivat $35 \mathrm{~kg} \mathrm{ha}^{-1}, 16 \mathrm{~kg} \mathrm{ha}^{-1}$ ja $69 \mathrm{~kg} \mathrm{ha}^{-1}$ ja vastaavat liukoisen typen taseet $-1 \mathrm{~kg}$ $\mathrm{ha}^{-1}, 1 \mathrm{~kg} \mathrm{ha}^{-1}$ ja $45 \mathrm{~kg} \mathrm{ha-1}$. Saadut tulokset ovat linjassa ja tukevat aiemmin koeolosuhteissa tehtyjä kokeita. Ravinnetasetulosten perusteella nurmi on tehokas ravinteiden hyödyntäjä ja pystyy tehokkaasti hyödyntämään maan ravinnereservejä. Runsaan kaliumoton vuoksi säilörehun kaliumpitoisuudet olivat korkeita vaihdellen niittojen välillä 25.0-29.5 g kg ha-1. Lannoituksen suunnittelussa tulisikin viljavuusanalyysin tuloksen lisäksi käyttää maan reservikaliumin määritystä sekä säilörehun kivennäisanalyysiä. Karjanlannan ravinteiden tehokkaan hyödyntämisen takia karjanlanta tulisi levittää niin, että levityksen jälkeen korjataan vielä kaksi satoa. Karjanlannan levittämisen yhteydessä typpitaseet jäivät reilusti positiivisiksi kyseisessä sadossa. Seuraavan sadon typpitaseet olivat negatiiviset. Uusien jalostettujen nurmilajikkeiden käyttö, korkeiden satotasojen tavoittelu ja kolme korjuuta voivat luoda ongelman ravinteiden riittävyyteen sekä köyhdyttää maan ravinnevaroja. Ravinnetaseiden avulla nurmenlannoitus voidaan suunnitella ympäristön kannalta vähemmän kuormittavaksi ja taloudellisemmaksi viljelijän kannalta.

Asiasanat: nurmi, päiste, tiivistymä, satotaso, ravinnetase, typpi, fosfori, kalium, karjanlanta 


\section{Johdanto}

Itä-Suomen vesistöt ovat valtaosin vähintään hyvässä ekologisessa tilassa. Alueella on kuitenkin huomattava määrä kohteita, joiden tilaa olisi parannettava. Koska maatalous on merkittävä fosforin vesistökuormituksen lähde, maatalouden osalle on asetettu fosforikuormituksen vähentämistarpeita (Mononen ym. 2016, Vallinkoski ym. 2016). Luonnonvarakeskuksen ja Yara Suomi Oy:n Maaningalla ja Ruukissa toteutetuissa pitkäaikaisissa nurmikokeissa kumulatiivinen fosforitase on ollut suositusten mukaisella lannoituksella negatiivinen ja laskusuuntainen (keskimäärin $\mathrm{n} .-9 \mathrm{~kg} \mathrm{P} \mathrm{ha-1} \mathrm{v}^{-1}$ ), mikä on koevuosien aikana alentanut muokkauskerroksen viljavuusfosforin pitoisuutta (Messiga ym. 2015). Karjanlannan käyttö ei ole nostanut maan viljavuusfosforia ja monissa tapauksissa karjanlannan fosfori on ollut nurmille riittävä fosforilannoitus (Mustonen ym. 2014). Eri puolilta Suomea vuosilta 1988-2014 kootussa peltolohkoaineistotarkastelussa kotieläinlantaa saaneilla säilörehunurmilohkoilla kokonaistyppitase oli noin $34 \mathrm{~kg} \mathrm{ha}^{-1}$ suurempi kuin vain väkilannoitetyppeä saaneilla lohkoilla, savimailla ero oli tätä pienempi. Liukoisen typen mukaan laskettaessa taseet olivat samalla tasolla. Tulokset osoittavat, että typpilannoituksen käyttö on tehostunut ja typpitaseet vaihtelevat merkittävästi viljelykasvin, satotason, maalajin ja sääolojen välillä (Turtola ym. 2017). Turtola ym. (2017) ovatkin ehdottaneet nykyisen ympäristökorvauksen korvaamista ravinnetaseisiin perustuvalla lannoituksella. Tämä hyödyntäisi huippusatojen tuottajia ja kannustaisi tavoittelemaan korkeampia satotasoja nurmesta. Karjatiloilla lannoituksen perustan muodostaa useimmiten lietteen levitys. Konekaluston kasvun myötä ja tehokkaan ravinteiden hyväksikäytön kannalta maan tiivistymisriski on syytä ottaa huomioon. Tulokset Jokioisen savimaalle perustetulta tiivistämiskokeelta osoittavat, että tiivistymisen pitkäaikaisvaikutukset olivat havaittavissa pohjamaan rakenteessa vielä lähes 30 vuotta tiivistämisen jälkeen (Schjønning ym. 2013). Kun lietettä levitetään kasvavaan nurmeen, voi pintamaan tiivistymisellä ja kasvuston tallauksella olla myös välittömiä ja lyhytaikaisia satovaikutuksia.

Ravinnerenki-hankkeen yleistavoitteena on maatilojen ravinnetalouden tehostaminen, ravinnehävikkien vähentäminen ja sitä kautta lannoituksen taloudellisen kannattavuuden parantaminen. Hanke toimii ItäSuomen alueella, jossa pääpaino on maidon- ja lihantuotannossa ja myös nurmentuotanto on keskittynyt samalle alueelle. Vuonna 2016 nurmenviljelyssä oli hieman yli puolet (55\%) Pohjois-Savon ja PohjoisKarjalan maatalousmaan pinta-alasta (SVT: Luonnonvarakeskus, Käytössä oleva maatalousmaa). Tiloilla tehtävän tutkimustyön tavoitteena oli selvittää maatilan ravinnevirtoja ja nurmen ravinteiden ottoon sekä satotasoihin vaikuttavia tekijöitä. Tiivistymisnäkökulman vuoksi tarkasteltiin lisäksi pyörän jälkien, tallaamattoman pellon ja päisteiden satotasoja.

\section{Materiaalit ja menetelmät}

Tutkimuksessa oli mukana kolme pohjoissavolaista maidontuotantotilaa, Iisalmesta, Sonkajärveltä ja Nilsiästä. Jokaiselta tilalta valittiin yksi havaintolohko, jolle tehtiin ennen jokaista säilörehunkorjuuta havaintokäynti. Havaintokäyntien tarkoitus oli verrata nurmen satoa, tiheyttä ja rikkakasvipitoisuutta kolmen eri käsittelyn: päisteen, renkaanjäljen ja pellon välillä. Havaintopisteet valittiin lohkoilta satunnaisesti. Kehikon $50 * 50 \mathrm{~cm}$ alalta arvioitiin nurmen tiheys ja rikkakasvipitoisuus silmämääräisesti. Kehikon alalta tuoresato leikattiin saksilla noin viiden senttimetrin korkeuteen ja punnittiin käsikäyttöisellä vaa'alla. Toistoja tehtiin neljä jokaiselta käsittelyltä. Tulokset analysoitiin varianssianalyysillä käyttäen SAS 9.4-ohjelmiston Mixed-proseduuria ja parivertailut tehtiin Tukeyn testillä.

Lohkojen säilörehusadot punnittiin hankkeelle vuokratulla DG Dina 40 kannettavalla ajoneuvovaáalla. Punnitus suoritettiin punnitsemalla pysähtynyt yhdistelmä jokainen akseli kerrallaan. Yhdistelmät punnittiin myös tyhjänä samalla toimintaperiaatteella. Kuormapainojen ja yhdistelmän tyhjäpainon erotuksena saatiin lohkon tuoresadon määrä. Säilörehuanalyysia varten jokaisesta säilörehukuormasta kerättiin rehunäyte, joista koostettiin yhteisnäyte koko lohkolle. Säilörehunäytteet toimitettiin analysoitavaksi Valio Oy:n Seinäjoen laboratorioon. Näytteistä analysoitiin fosfori (P, g kg ka $\left.{ }^{-1}\right)$ ja kalium (K, g kg ka-1) XRF-menetelmällä ja raakavalkuainen (rv, g kg ka ${ }^{-1}$ ) NIR-menetelmällä.

Punnitut lohkokohtaiset tuoresadot muunnettiin kuiva-ainekiloiksi säilörehuanalyysin kuivaainepitoisuuden perusteella. Satotason ja säilörehuanalyysin perusteella laskettiin jokaiselle niitolle ja 
kokonaissadolle ravinnetaseet ja lannoituksen hyötysuhteet. Peltoon lisätyt ravinteet on laskettu lannoitteenmyyjien lannoitteillensa ilmoittamien pitoisuuksien mukaan. Tukiehdot edellyttävät, että tiloilla on voimassa oleva lanta-analyysi, jonka perusteella on laskettu lietteen mukana annetut ravinteet. Sadoissa poistuneet ravinteet laskettiin säilörehuanalyysin raakavalkuaisen ja kivennäisanalyysin perusteella. Ravinnetase on laskettu peltoon lisättyjen ja sadon mukana poistuneiden ravinteiden erotuksena. Typpitase on laskettu erikseen karjanlannan liukoisella ja kokonaistypellä. Hyötysuhde on laskettu jakamalla peltoon lisätyt ravinteet sadon mukana poistuneilla ravinteilla ja kertomalla sadalla. Havaintolohkojen viljelytoimenpiteet on toteutettu ympäristökorvausehtojen, täydentävien ehtojen ja nitraattiasetuksen puitteissa.

\section{Havaintolohkojen viljelytoimenpiteet}

Iisalmen havaintolohko (6.88 ha) oli ensimmäisen vuoden säilörehunurmi, jota oli täydennetty kolmas toukokuuta timoteitä, nurminataa, ruokonataa ja puna-apilaa sisältävällä seoksella. Ensimmäisen sadon lannoitukseen oli käytetty $78 \mathrm{~kg}$ typpeä ja $3 \mathrm{~kg}$ kaliumia (290 kg ha-1 YaraBela Suomensalpietaria). Toisen sadon lannoitukseen oli sijoitettu liete $\left(30 \mathrm{t} \mathrm{ha}^{-1}\right): 87 \mathrm{~kg}$ kokonaistyppeä, josta $51 \mathrm{~kg}$ liukoista typpeä, $15 \mathrm{~kg}$ fosforia ja $87 \mathrm{~kg}$ kaliumia sekä annettu väkilannoitus: $27 \mathrm{~kg}$ typpeä ja $1 \mathrm{~kg}$ kaliumia (100 $\mathrm{kg} \mathrm{ha}^{-1}$ YaraBela Seleenisalpietaria). Kolmannen sadon lannoitukseen oli käytetty $27 \mathrm{~kg}$ typpeä ja $1 \mathrm{~kg}$ kaliumia (100 kg ha-1 YaraBela Seleenisalpietaria). Säilörehun korjuuajankohdat olivat 4.6., 18.7. ja 26.8. Lohkon maalaji oli multava hiue/hieno hieta. Säilörehusatoja tehtiin kolme, mutta kolmatta havaintokäyntiä ei ehditty tekemään nopean säilörehun korjuun aloituksen takia. Sonkajärven havaintolohko (2.09 ha) oli toisen vuoden timotei-nurminata-ruokonata -säilörehunurmi. Ensimmäisen sadon lannoitukseen oli sijoitettu liete $\left(25 \mathrm{t} \mathrm{ha}^{-1}\right)$ : $63 \mathrm{~kg}$ kokonaistyppeä, josta $47.5 \mathrm{~kg}$ liukoista typpeä, $5 \mathrm{~kg}$ fosforia ja $45 \mathrm{~kg}$ kaliumia sekä väkilannoitteena $54 \mathrm{~kg}$ typpeä (Belor Premiun typpi $200 \mathrm{~kg} \mathrm{ha}^{-1}$ ). Toisen sadon lannoitukseen oli käytetty 81 kg typpeä ja 3 kg kaliumia (YaraBela Seleenisalpietari 300 $\mathrm{kg} \mathrm{ha}^{-1}$ ). Kolmannen sadon lannoitukseen oli käytetty 23 kg typpeä ja 8 kg kaliumia (YaraMila NK3 100 $\mathrm{kg} \mathrm{ha}^{-1}$ ). Säilörehun korjuuajankohdat olivat 7.6., 27.7. ja 14.9. Lohkon maalaji oli runsasmultainen hietamoreeni. Nilsiän havaintolohko (7.36 ha) oli neljännen vuoden timotei-nurminata-puna-apila säilörehunurmi. Ensimmäisen sadon lannoitukseen oli levitetty liete (30 t ha $\left.{ }^{-1}\right)$ pintaan: $69 \mathrm{~kg}$ kokonaistyppeä, josta $45 \mathrm{~kg}$ liukoista typpeä, $7 \mathrm{~kg}$ fosforia ja $48 \mathrm{~kg}$ kaliumia sekä väkilannoitteena 67.5 kg typpeä ja $2.5 \mathrm{~kg}$ kaliumia (YaraBela Seleenisalpietari $250 \mathrm{~kg} \mathrm{ha}^{-1}$ ). Toisen sadon lannoitukseen oli käytetty 66 kg typpeä ja 36 kg kaliumia (YaraMila NK2 $300 \mathrm{~kg} \mathrm{ha}^{-1}$ ). Säilörehun korjuuajankohdat olivat 6.6. ja 24.7. Lohkon maalaji oli multava hiue/hieno hieta.

\section{Tulokset}

\section{Havaintokäynnit}

Kehikkonäytteiden ja havaintojen avulla pyrimme selvittämään vaikuttaako peltoliikenteen aiheuttama tiivistymä nurmen satotasoeroihin pellon, renkaanjäljen ja päisteiden välillä. Käsittelyt eroavat toisistaan tilastollisesti merkitsevästi, jos $\mathrm{P}<0.05$. Ensimmäisessä niitossa päisteen satotaso oli peltoa matalampi jokaisella havaintolohkolla (Taulukko 1).

Taulukko 1. Tuoresadot $\left(\mathrm{kg} \mathrm{ha}^{-1}\right)$ niitoittain. SEM = keskiarvon keskivirhe. Käsittelyt eroavat toisistaan tilastollisesti merkitsevästi, jos ne on merkitty eri kirjaimella.

\begin{tabular}{llccccc}
\multicolumn{2}{l}{ Tuoresato kg ha ${ }^{-1}$} & Pelto & Päiste & Renkaan jälki & SEM & Merkitsevyys \\
\hline \multirow{2}{*}{ Iisalmi } & Niitto 1 & $17000 \mathrm{~b}$ & $6200 \mathrm{a}$ & $17800 \mathrm{~b}$ & 1924 & $* *$ \\
& Niitto 2 & $34000 \mathrm{~b}$ & $6800 \mathrm{a}$ & $28800 \mathrm{~b}$ & 1876 & $* * *$ \\
\multirow{2}{*}{ Sonkajärvi } & Niitto 1 & $21200 \mathrm{~b}$ & $12600 \mathrm{a}$ & $21200 \mathrm{~b}$ & 1870 & $*$ \\
& Niitto 2 & $17600 \mathrm{~b}$ & $3200 \mathrm{a}$ & $14100 \mathrm{~b}$ & 1851 & $* *$ \\
\multirow{5}{*}{ Nilsiä } & Niitto 3† & 11000 & 3100 & 6000 &. & 0 \\
& Niitto 1 & $18200 \mathrm{~b}$ & $8800 \mathrm{a}$ & $8300 \mathrm{a}$ & 1996 & $*$ \\
& Niitto 2 & 7400 & 6400 & 2100 & 1446 & 0 \\
\hline
\end{tabular}

*** $\mathrm{P}<0.001, * * \mathrm{P}<0.01, * \mathrm{P}<0.05,0 \mathrm{P}<0.10$

$\dagger$ Käytetty logaritmimuunnosta.

Toisessa niitossa päisteen satotaso oli peltoa matalampi Iisalmen ja Sonkajärven havaintolohkoilla. Päisteen satotaso oli renkaanjälkeä matalampi ensimmäisessä ja toisessa niitossa Iisalmessa ja 
Sonkajärvellä. Ainoastaan Nilsiän ensimmäisessä niitossa renkaan jäljen satotaso oli matalampi kuin pellon.

Aukkoisuusprosenteissa havaittiin vain vähän tilastollista merkitsevyyttä päisteen, pellon ja renkaanjäljen välillä (Taulukko 2). Päiste oli peltoa ja renkaanjälkeä aukkoisempi ensimmäisessä niitossa Iisalmessa ja lähes merkitsevästi myös Sonkajärvellä. Iisalmen ensimmäisessä niitossa päisteessä oli enemmän rikkakasveja kuin pellolla ja renkaanjäljessä (Taulukko 2). Sonkajärven toisessa niitossa havaittiin rikkakasveja olevan enemmän päisteessä, kuin pellolla ja renkaanjäljessä ja ensimmäisessä niitossa enemmän kuin renkaan jäljessä. Nilsiässä ensimmäisessä niitossa rikkakasveja oli vähemmän renkaanjäljessä kuin pellossa.

Taulukko 2. Aukkoisuus ja rikkakasviprosentit niitoittain. SEM = keskiarvon keskivirhe. Käsittelyt eroavat toisistaan tilastollisesti merkitsevästi, jos ne on merkitty eri kirjaimella.

\begin{tabular}{|c|c|c|c|c|c|c|}
\hline Aukkoisuus-\% & & Pelto & Päiste & Renkaan jälki & SEM & Merkitsevyys \\
\hline \multirow{2}{*}{ Iisalmi } & Niitto 1 & 29 a & $65 \mathrm{~b}$ & $23 \mathrm{a}$ & 5.4 & $* * *$ \\
\hline & Niitto 2 & 24 & 30 & 18 & 8.2 & \\
\hline \multirow{3}{*}{ Sonkajärvi } & Niitto 1 & 28 & 48 & 25 & 7.1 & 0 \\
\hline & Niitto 2 & 24 & 38 & 29 & 5.6 & \\
\hline & Niitto 3 & 41 & 58 & 44 & 5.9 & \\
\hline \multirow{2}{*}{ Nilsiä } & Niitto 1 & 21 & 26 & 28 & 5.9 & \\
\hline & Niitto 2 & 26 & 21 & 20 & 7.4 & \\
\hline Rikkakasvi-\% & & Pelto & Päiste & Renkaan jälki & SEM & Merkitsevyys \\
\hline \multirow{2}{*}{ Iisalmi } & Niitto 1 & $4 \mathrm{a}$ & $46 \mathrm{~b}$ & $6 \mathrm{a}$ & 2.4 & $* * *$ \\
\hline & Niitto 2 & 23 & 15 & 8 & 6.2 & \\
\hline \multirow{3}{*}{ Sonkajärvi } & Niitto $1 \dagger$ & $4 \mathrm{ab}$ & $16 \mathrm{~b}$ & $1 \mathrm{a}$ & . & $*$ \\
\hline & Niitto 2 & $9 \mathrm{a}$ & $44 \mathrm{~b}$ & $18 \mathrm{a}$ & 6.0 & $* *$ \\
\hline & Niitto 3 & 5 & 26 & 15 & 5.2 & 0 \\
\hline \multirow{2}{*}{ Nilsiä } & Niitto 1 & $8 \mathrm{~b}$ & $6 \mathrm{ab}$ & $1 \mathrm{a}$ & 1.3 & $*$ \\
\hline & Niitto 2 & 9 & 11 & 16 & 4.3 & \\
\hline
\end{tabular}

*** $\mathrm{P}<0.001$, ** $\mathrm{P}<0.01$, * $\mathrm{P}<0.05,0 \mathrm{P}<0.10$

$\dagger$ Käytetty logaritmimuunnosta.

\section{Satotasot}

Kuvassa 1 on esitetty punnitut satotasot $(\mathrm{kg} \mathrm{ka} \mathrm{ha-1).} \mathrm{ProAgrian} \mathrm{Lohkotietopankin} \mathrm{mukaan}$ keskimääräinen satotaso on Suomessa noin $6000 \mathrm{~kg} \mathrm{ka} \mathrm{ha}^{-1}$. Iisalmen havaintolohkon satotaso oli 7900 kg ka ha ${ }^{-1}$, Sonkajärven havaintolohkon satotaso oli $9100 \mathrm{~kg} \mathrm{ka} \mathrm{ha}^{-1}$ ja Nilsiän havaintolohkon satotaso oli $5500 \mathrm{~kg} \mathrm{ka} \mathrm{ha}^{-1}$. Iisalmen ja Sonkajärven havaintolohkoilla päästiin yli keskiarvon.

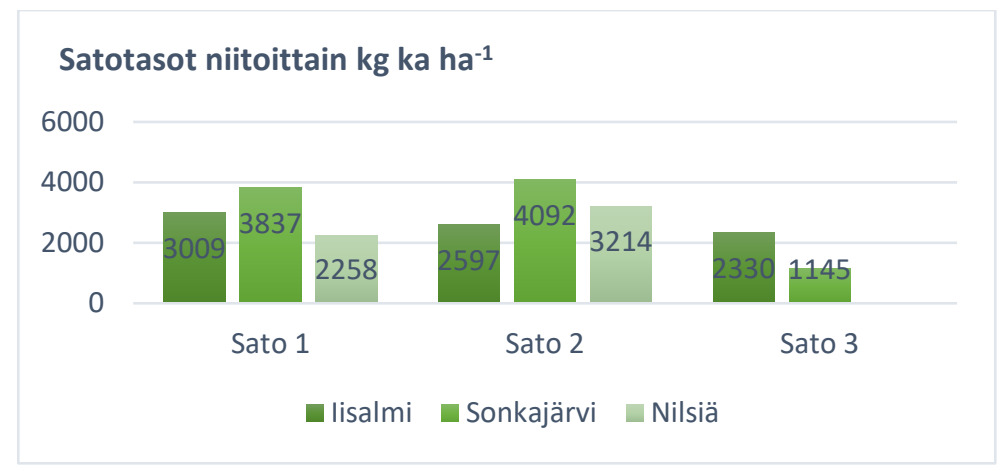

Kuva 1. Satotasot paikkakunnittain ja niitoittain.

Nilsiän havaintolohkon satotaso jäi alle keskimääräisen. Korkein satotaso saatiin toisen vuoden nurmesta ja alhaisin neljännen vuoden nurmesta. Yleensä ensimmäisen sadon satopotentiaali on suurin, 
mutta Sonkajärvellä ja Nilsiässä päästiin korkeampiin satotasoihin toisessa sadossa. Eri ajankohtaan tehty sadonkorjuu on voinut vaikuttaa tilojen satotasoeroihin.

\section{Ravinnetaseet}

Kuvassa 2 on kuvattu kasvukauden kokonaissadolle annetut ravinteet, ravinnepoistumat ja taseet Iisalmen havaintolohkolta. Liukoinen typpitase oli $-1 \mathrm{~kg} \mathrm{ha}^{-1}$, kokonaistyppitase $35 \mathrm{~kg} \mathrm{ha}^{-1}$, fosforitase $-8 \mathrm{~kg} \mathrm{ha}^{-1}$ ja kaliumtase $-133 \mathrm{~kg} \mathrm{ha}^{-1}$. Lohkon viljavuuskalium oli luokassa välttävä $\left(110 \mathrm{mg} \mathrm{l}^{-1}\right)$ ja huononlainen (64 $\left.\mathrm{mg} \mathrm{l}^{-1}\right)$ ja viljavuusfosfori luokassa välttävä $\left(6.5 \mathrm{mg} \mathrm{I}^{-1}\right)$ ja tyydyttävä $\left(12 \mathrm{mg} \mathrm{l}^{-1}\right)$. Fosforipitoisuudet säilörehussa olivat 2.6-3.0 $\mathrm{g} \mathrm{kg} \mathrm{ka}^{-1}$. Kaliumpitoisuudet säilörehussa olivat korkeita, 27-29 $\mathrm{g} \mathrm{kg} \mathrm{ka}^{-1}$.

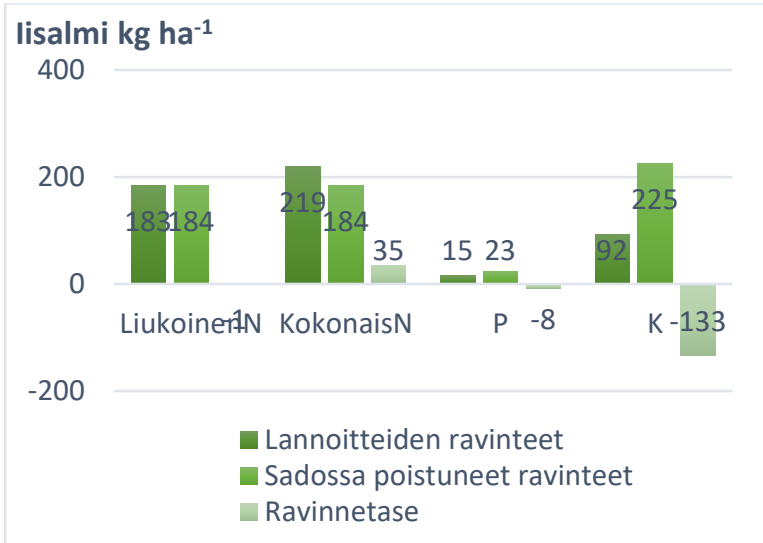

Kuva 2. Kokonaissadon taseet Iisalmi.

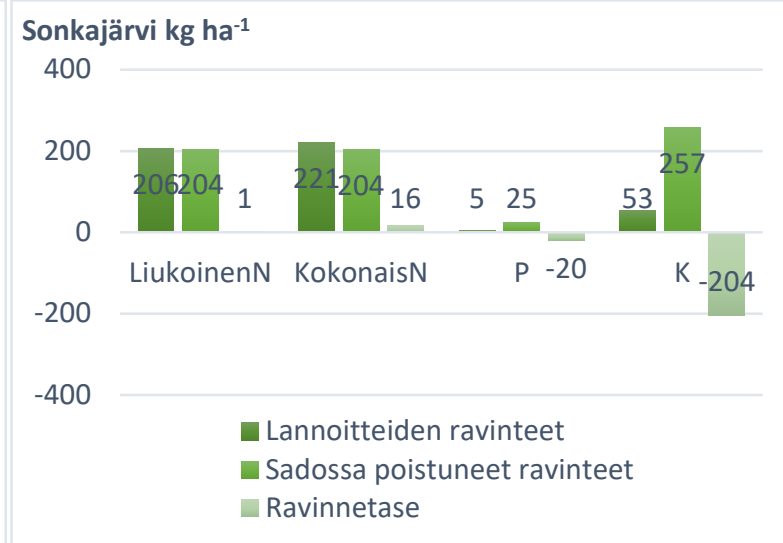

Kuva 3. Kokonaissadon taseet Sonkajärvi.

Kuvassa 3 on kuvattu kasvukauden kokonaissadolle annetut ravinteet, ravinnepoistumat ja taseet Sonkajärven havaintolohkolta. Sonkajärven satotaso oli suurin ja myös ravinteidenotto tehokkainta. Satotason noustessa nurmen fosforin ja kaliumin otto kasvoi. Liukoinen typpitase oli $1 \mathrm{~kg} \mathrm{ha}^{-1}$, kokonaistyppitase $16 \mathrm{~kg} \mathrm{ha}^{-1}$, fosforitase $-20 \mathrm{~kg} \mathrm{ha}^{-1}$ ja kaliumtase $-204 \mathrm{~kg} \mathrm{ha}^{-1}$. Viljavuustutkimuksen mukaan lohkon viljavuusfosfori oli luokassa hyvä (19.3 $\left.\mathrm{mg} \mathrm{l}^{-1}\right)$, mikä rajoittaa fosforilannoituksen enimmäismäärän $5 \mathrm{~kg} \mathrm{ha}^{-1} \mathrm{v}^{-1}$. Maan viljavuuskalium oli analyysin mukaan luokassa tyydyttävä (160 $\mathrm{mg} \mathrm{l}^{-1}$ ) ja hyvä (200 mg l$\left.{ }^{-1}\right)$. Fosforipitoisuudet säilörehussa olivat 2.6-2.9 g kg ka-1. Kaliumpitoisuudet säilörehussa olivat korkeita, 27-29.5 g kg ka-1.

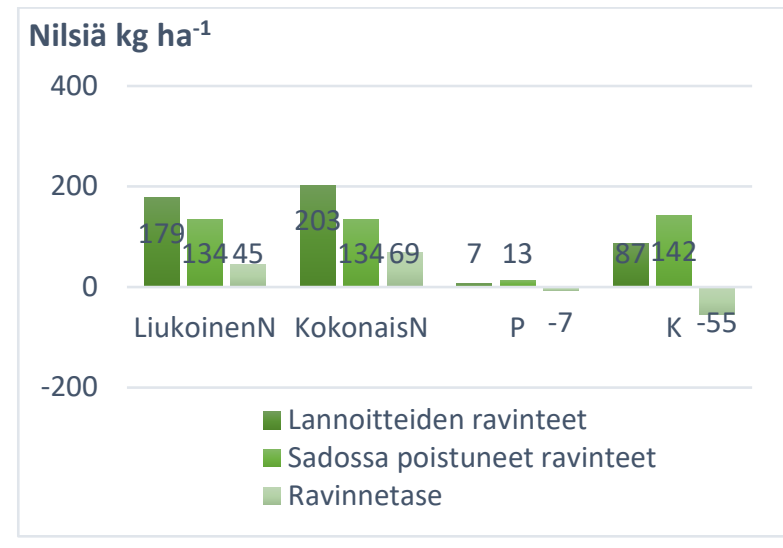

Kuva 4. Kokonaissadon taseet Nilsiä.

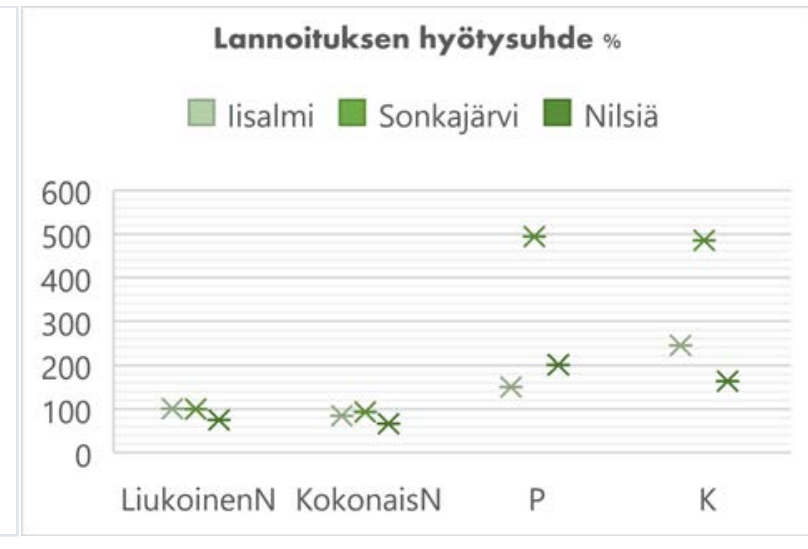

Kuva 5. Lannoituksen hyötysuhteet.

Kuvassa 4 on kuvattu kasvukauden kokonaissadolle annetut ravinteet, ravinnepoistumat ja taseet Nilsiän havaintolohkolta. Nilsiän neljännen vuoden nurmen satotaso jäi alhaiseksi ja myös ravinteiden hyödyntäminen oli heikkoa. Liukoinen typpitase oli $45 \mathrm{~kg}^{\mathrm{ha}}{ }^{-1}$, kokonaistyppitase oli $69 \mathrm{~kg} \mathrm{ha}^{-1}$, fosforitase $-7 \mathrm{~kg} \mathrm{ha}^{-1}$ ja kaliumtase $-55 \mathrm{~kg} \mathrm{ha}^{-1}$. Viljavuusfosfori oli luokassa välttävä (5.0 $\mathrm{mg} \mathrm{l}^{-1}$ ja 8.9 $\left.\mathrm{mg} \mathrm{l}^{-1}\right)$, ja kalium luokassa huononlainen $\left(67 \mathrm{mg} \mathrm{l}^{-1}\right)$ ja tyydyttävä $\left(132 \mathrm{mg} \mathrm{l}^{-1}\right)$. Fosforipitoisuudet säilörehussa olivat 2.0-2.6 g kg ka ${ }^{-1}$. Kaliumpitoisuudet säilörehussa olivat alhaisimmat havaintolohkoista, 25-26.7 $\mathrm{g} \mathrm{kg} \mathrm{ka}^{-1}$. 
Kuvassa 5 on esitetty lannoituksen hyötysuhde kokonaissadon taseista. Hyötysuhde kertoo prosentuaalisen osuuden viljelykasvin hyödyntämistä ravinteista. Hyötysuhteen ollessa yli $100 \%$, on kasvi ottanut ravinteita enemmän kuin on annettu. Liukoisen typen hyötysuhde oli Iisalmen havaintolohkolla 101\% ja kokonaistypen 84\%. Liukoisen typen hyötysuhde oli Sonkajärven havaintolohkolla 99\% ja kokonaistypen 93\%. Nilsiän havaintolohkolla liukoisen typen hyötysuhde oli 75\%. ja kokonaistypen 66\%. Fosforin hyötysuhde oli Iisalmen havaintolohkolla 151\%, Sonkajärven havaintolohkolla 494\% ja Nilsiän havaintolohkolla 201\%. Kaliumin hyötysuhde oli Iisalmen havaintolohkolla 245\%, Sonkajärven havaintolohkolla 486\% ja Nilsiän havaintolohkolla 164\%.

\section{Tulosten tarkastelu}

Päisteiden alhaiseen satotasoon tulisi tiloilla kiinnittää huomiota. Päisteiden alhaisen satotason osuus korostuu, jos tilalla on paljon pieniä, hankalanmuotoisia ja metsän reunaan rajoittuvia lohkoja. Tilusjärjestelyn avulla lohkokokoja olisi mahdollista saada suurennettua. Koneilla kääntyilyä voisi lohkolla vähentää lisäämällä mahdollisuuksien mukaan liittymiä lohkoille. Päisteiden osuus tulisi huomioida myös lannoituksessa ja pyrkiä täsmälannoitukseen kasvuston mukaan. Näiden havaintojen mukaan muualla kuin päisteessä sijaitsevien renkaanjälkien satotaso ei juuri eronnut pellon satotasosta.

Ravinnetaselaskelmien perusteella monivuotiset nurmikasvit hyödynsivät ravinteita tehokkaasti. Negatiiviset ja lähellä nollaa olevat ravinnetaseet kertovat taloudellisesta lannoituksesta. Nurmien on todettu pystyvän hyödyntämään pitkän kasvukautensa ja syvälle ulottuvan juuriston avulla maan ravinnereservejä (Virkajärvi ym. 2014). Ravinnetaselaskelmat osoittavat, ettei ainoastaan viljavuusanalyysi ole tarkka maan ravinnevarojen ennustaja. Varsinkin kaliumia näyttäisi poistuvan sadon mukana runsaasti, vaikka viljavuuskalium on luokassa välttävä ja huononlainen. Lannoituksen suunnittelussa tulisi viljavuustietojen lisäksi huomioida myös säilörehuanalyysin kivennäispitoisuudet sekä maan ravinnereservit, erityisesti kaliumin osalta. Reservikaliumnäytteet voi kerätä maalajiltaan samankaltaisilta peltolohkoilta. Jankosta voi ottaa erillisen näytteen, jos jankon maalaji eroaa kyntökerroksen maalajista. Alhaisen reservikaliumtilan mailla kaliumin tarve korostuu. Korkean reservikaliumtilan mailla ongelmaksi voi muodostua säilörehun korkeat kaliumpitoisuudet. Positiivisia nurmen kaliumtaseita ei kannata tavoitella, koska nurmi ottaa kaliumia noin 150-250 kg ha ${ }^{-1} \mathrm{v}^{-1}$. Kaliumvarojen köyhtymistä hyvän reservikaliumtilan mailla ei kannata pelätä, koska ulkomaalaisten tutkimusten mukaan kaliumvarat voivat kestää jopa joitakin satoja vuosia (Andrist-Rangel 2008).

Karjanlannan havaittiin vaikuttavan typen osalta myös seuraavan sadon ravinnetaseeseen. Karjanlannan levityksen yhteydessä kyseisen sadon liukoinen typpitase sekä kokonaistyppitase jäivät positiiviseksi ja seuraavan sadon molemmat typpitaseet reilusti negatiiviseksi. Karjanlannassa on kasveille välittömästi käyttökelpoista epäorgaanista typpeä (ammonium- ja nitraattityppi) ja hitaammin vapautuvaa orgaanista typpeä, jonka on ensin mineralisoiduttava kasveille käyttökelpoiseen epäorgaaniseen muotoon. Naudan lietelannan kokonaistypestä keskimäärin 57\% on liukoista typpeä (Eurofins Viljavuuspalvelu Oy 2018), joka on tyypillisesti valtaosin epäorgaanisessa ammoniummuodossa. Väkilannoitteiden typpi on kokonaisuudessaan epäorgaanisessa muodossa, josta noin puolet on nitraattityppeä ja toiset puolet ammoniumtyppeä. Lannan typen satovasteen hyödyntämiseksi lanta suositellaan levitettäväksi nurmelle siten, että levityksen jälkeen korjataan vielä kaksi satoa. Kolmen niiton systeemissä suotuisin levitysajankohta on toiselle sadolle (Kapuinen ym. 2007). Käytännön töissä sääolosuhteet usein määräävät lannanlevityksen ajankohdan.

Tutkimuksissa on havaittu, jos maan viljavuusfosfori on luokassa tyydyttävä tai korkeampi ei fosforilannoituksen lisäämisellä ole todettu olevan vaikutusta satotasoon (Mustonen ym. 2014). Valkaman ym. (2015) mukaan vuotuisella fosforilannoituksella ei saavuteta sadonlisää, kun maan viljavuusfosforin pitoisuus ylittää savimailla $6 \mathrm{mg} \mathrm{l}^{-1}$, karkeilla kivennäismailla $10 \mathrm{mg} \mathrm{l}^{-1}$ ja orgaanisilla mailla $15 \mathrm{mg} \mathrm{l}^{-1}$. Fosforirikkailla lohkoilla maan fosforitilan alentaminen on lannoituskustannusten ja fosforin huuhtoutumisriskin kannalta suositeltavaa. Kivennäismailla nurmen sadontuoton kannalta fosforilannoitusta tärkeämpiä ovat typpilannoituksen optimointi ja maan rakenne, kun taas orgaanisilla mailla korostuu pH:n vaikutus ja kalkituksen merkitys. Laskennallinen fosfori-typpisuhde säilörehussa oli jokaisella havaintolohkolla yli 0.1, joka tarkoittaa, ettei fosfori ole rajoittanut nurmen kasvua. Saarela (2005) on esittänyt, että fosforin ja typen suhteen ollessa säilörehussa 0.125 on se riittävä 
fosforipitoisuuden alaraja. On kuitenkin huomioitava, että nurmi on hyödyntänyt osan fosforista maan reserveistä ja jatkuva negatiivinen fosforitase köyhdyttää maan fosforivaroja ja alentaa viljavuusluokkaa. Ruokinnan näkökulmasta perinteisellä rypsin valkuaiseen perustuvalla ruokinnalla, fosforipitoisuus ei kovin helposti laske vaarallisen alas lypsävillä lehmillä. Rypsin fosforipitoisuus on niin korkea, että se pystyy turvaamaan lypsylehmän fosforin tarpeen lypsykaudella, vaikka säilörehun fosforipitoisuus laskee $2 \mathrm{~g} \mathrm{~kg} \mathrm{ka}^{-1}$. Erilaisissa muutosvaiheissa ja tilanteessa, jossa lehmä ei syö hyvin, vajeita voi muodostua (Turpeinen ja Rantala 2017).

\section{Johtopäätökset}

Koko tilan pinta-alasta päisteiden osuus voi muodostua merkittäväksi satotasoa alentavaksi tekijäksi. Nurmi on tehokas ravinteiden hyödyntäjä ja pystyy hyödyntämään myös maan ravinnereservejä. Uusien jalostettujen nurmilajikkeiden käyttö, korkeiden satotasojen tavoittelu ja kolme korjuuta voivat luoda ongelman ravinteiden riittävyyteen sekä köyhdyttää maan ravinnevaroja. Vesistöjen suojelun ja ravinteiden täysimääräisen hyödyntämisen kannalta lannoituksen suunnittelussa tulisi ottaa huomioon lohkon odotettavissa oleva satotaso, maan ravinnereservit, säilörehuanalyysi sekä karjanlannan levityksen ajankohta. Ravinnetaselaskelmien pohjalta lannoitusta voi säätää tehokkaampaan, taloudellisempaan ja ympäristöystävällisempään suuntaan.

\section{Kiitokset}

Tutkimus on toteutettu Euroopan maaseudun kehittämisen maatalousrahaston rahoittamassa Ravinnerenki-hankkeessa. Kiitokset havaintomaatiloillemme sekä kärsivällisille säilörehun tekijöille.

\section{Kirjallisuus}

Andrist-Rangel, Y. 2008. Quantifying mineral sources of potassium in agricultural soils. Doctoral Thesis. Swedish University of Agricultural Sciences, Uppsala. 105 s. 19 liitesivua.

Eurofins Viljavuuspalvelu Oy 2018. Lantatilasto vuosilta 2006-2009. Viitattu 23.1.2018. http://viljavuuspalvelu.fi/sites/default/files/sites/default/files/tilastot/Lantatilasto\%202005\%20-\%202009.pdf. Kapuinen, P., Perälä, P. \& Regina, K. 2007. Digested slurry as a fertilizer for biogas ley. Julkaisussa: NJF Seminar 405: Production and Utilization of Crops for Energy, Vilnius, Lithuania, 25-26 September 2007. NJF Report 3: 60-65.

Messiga, A.J., Ziadi, N., Jouany, C., Virkajärvi, P., Suomela, R., Sinaj, S., Bélanger, G., Stroia, C. \& Morel, C. 2015. Soil test phosphorus and cumulative phosphorus budgets in fertilized grassland. AMBIO 44: S252-S262.

Mononen, P. Käki, T. Ranta, P. \& Rämö, A. 2016. Pohjois-Karjalan vesienhoidon toimenpideohjelma vuosille 2016-2021.Raportteja 5/2016. Pohjois-Karjalan elinkeino-, liikenne- ja ympäristökeskus. 185 s.

Mustonen, A. Virkajärvi, P. Hyrkäs, Suomela, M. \& Kauppila, R. 2014. Seitsemän lihavaa vuotta - vieläkö nurmen fosforilannoituksesta voidaan tinkiä? Teoksessa: Maataloustieteen Päivät 2014, 8.-9.1.2014 Viikki, Helsinki. Suomen Maataloustieteellisen seuran tiedote: $31.7 \mathrm{~s}$.

Saarela, I. 2005. Nurmen fosforitalous. Nurmitieto 2.2.2. Suomen Nurmiyhdistyksen ja MTT:n julkaisusarja. Julkaisupäivä: 17.3.2005. Viitattu 23.1.2018. https://portal.mtt.fi/portal/page/portal/nurmiyhdistys/Nurmitieto/. Schjønning, P., Lamandé, M., Berisso, F.E., Simojoki, A., Alakukku, L. \& Andreasen, R.R. 2013. Gas diffusion, non-Darcy air permeability, and computed tomography images of a clay subsoil affected by compaction. Soil Science Society of America Journal 77: 1977-1990.

Turpeinen, E \& Rantala, J. 2017. ProAgria Pohjois-Savon ruokinnanasiantuntijoiden suullinen tiedonanto. Turtola, E., Salo, T., Miettinen, A., Iho, A., Valkama, E., Rankinen, K., Virkajärvi, P., Tuomisto, J., Sipilä, A., Muurinen, S., Turakainen, M., Lemola, R., Jauhiainen, L., Uusitalo, R., Grönroos, J., Myllys, M., Heikkinen, J., Merilaita, S., Bernal, J.C., Savela, P., Kartio, M., Salopelto, J., Finér, A. \& Jaakkola, M. 2017. Hyötyä taseista Ravinnetaseiden tulkinta ympäristön ja viljelyn hyödyksi. https://jukuri.luke.fi/bitstream/handle/10024/538541/luke-luobio_15_2017.pdf?sequence=10\&isAllowed=y Vallinkoski, V-M., Miettinen, T. \& Aalto, J. 2016. Vesien tila hyväksi yhdessä. Pohjois-Savon vesienhoidon toimenpideohjelma vuosille 2016-2021. Raportteja 1/2016. Pohjois-Savon elinkeino-, liikenne- ja ympäristökeskus. $151 \mathrm{~s}$.

Virkajärvi, P., Kykkänen, S., Räty, M., Hyrkäs, M., Järvenranta, K., Isolahti, M. \& Kauppila, R. 2014. Nurmien kaliumtalous. Maan reservikaliumin merkitys kaliumlannoituksen suunnittelussa. MTT Raportti 165. 52 s. http://urn.fi/URN:ISBN:978-952-487-581-3 